\title{
Questes
}

\section{La mémoire du jongleur dans les sirventes ensenhamens occitans}

Silvère Menelgado

\section{Q OpenEdition}

1 Journals

\section{Édition électronique}

URL : http://journals.openedition.org/questes/2829

DOI : 10.4000/questes.2829

ISSN : 2109-9472

Éditeur

Les Amis de Questes

\section{Édition imprimée}

Date de publication : 15 décembre 2002

Pagination : 10-11

ISSN : 2102-7188

\section{Référence électronique}

Silvère Menelgado, "La mémoire du jongleur dans les sirventes ensenhamens occitans », Questes [En ligne], 2 | 2002, mis en ligne le 01 janvier 2014, consulté le 15 septembre 2020. URL : http:// journals.openedition.org/questes/2829

Ce document a été généré automatiquement le 15 septembre 2020.

(c) Association des amis de «Questes » 


\title{
La mémoire du jongleur dans les sirventes ensenhamens occitans
}

\author{
Silvère Menelgado
}

NOTE DE L'ÉDITEUR

Cet article n'a pas encore fait l'objet d'une autorisation de publication.

INDEX

Mots-clés : mémoire, jongleur, narration, fiction, ignorance, comique

Keywords : memory, jongleur, narration, fiction, ignorance, comic 